\title{
Organic iron(III) speciation in surface transects across a frontal zone: the Chatham Rise, New Zealand
}

\author{
Feng Tian ${ }^{\mathrm{A}, \mathrm{C}}$, Russell D. Frew ${ }^{\mathrm{A}}$, Sylvia Sander ${ }^{\mathrm{A}}$, Keith A. Hunter ${ }^{\mathrm{A}}$ and Michael J. Ellwood $^{\mathrm{B}}$ \\ ${ }^{A}$ Department of Chemistry, University of Otago, Dunedin, New Zealand. \\ ${ }^{B}$ National Institute of Water and Atmosphere, Hillcrest, Hamilton, New Zealand. \\ ${ }^{\mathrm{C}}$ Corresponding author. Email: ftian@alkali.otago.ac.nz
}

\begin{abstract}
Iron $(\mathrm{Fe})$ is a critical nutrient in marine systems and the organic complexation of $\mathrm{Fe}$ is a central factor of the marine biogeochemistry of $\mathrm{Fe}$. In the present study, total dissolved $\mathrm{Fe}$ and its organic speciation were measured in filtered seawater samples $(<0.2 \mu \mathrm{m})$ collected along three surface transects across the subtropical (ST) front, east of New Zealand, in austral spring (October 2000). Total dissolved Fe concentrations were low $(\sim 0.1 \mathrm{nM})$ in the subantarctic (SA) waters. The highest Fe concentration $(\sim 0.8 \mathrm{nM})$ was observed at the mixing boundary north of the Subtropical Convergence (STC) and then decreased relatively quickly both southward and northward. Cathodic stripping voltammetry was used to determine Fe speciation. The dissolved Fe(III) was fully complexed (>99.9\%) by natural organic ligands, which were found to occur in excess of the dissolved Fe concentration at $1.29 \pm 0.33 \mathrm{~nm}$ (equivalent to an excess over Fe of $\sim 1.0 \mathrm{nM}$ ), and with a complex stability of $\log K_{\mathrm{FeL}_{\text {, }}^{\prime}{ }^{3+}}=22.67 \pm 0.22$. The total ligand concentrations were consistently higher $(\sim 0.5 \mathrm{nM})$ in the ST and STC waters than in the SA waters. Our Fe data imply that the regional currents may be an important vehicle for transporting the elevated $\mathrm{Fe}$ across the front.
\end{abstract}

Extra keywords: organic speciation, subtropical front.

\section{Introduction}

Iron $(\mathrm{Fe})$ is an essential micronutrient for phytoplankton and plays an important role in regulating their growth in some regions of the ocean. It is an important constituent of such biochemical processes as photosynthesis, nitrate and nitrite reduction, and many other biosynthetic reactions (Sunda 1989; Hutchins 1995). In situ Fe fertilisation experiments and shipboard enrichment incubations have proven that $\mathrm{Fe}$ limits primary production in high-nutrient, low-chlorophyll (HNLC) regions, including the Subarctic Pacific, the Equatorial Pacific, and the Southern Ocean (Martin and Fitzwater 1988; Martin et al. 1994; Coale et al. 1996; Boyd et al. 2000, 2004a).

$\mathrm{Fe}$ is predicted to be present primarily in the form of $\mathrm{Fe}(\mathrm{III})$ oxy-hydroxides in oxic seawater (Turner et al. 1981; Hudson et al. 1990). It occurs at extremely low concentrations in the open ocean owing to the hydrolysis of thermodynamically stable Fe(III) compounds, and the resulting formation of sparingly soluble hydroxides and oxides. Voltammetric speciation methods have been developed to gain insight into the degree of complexation of Fe(III) with natural organic ligands in seawater. Electrochemical measurements (Gledhill and van den Berg 1994; Rue and Bruland 1995; Wu and Luther 1995) have shown that most of the dissolved $\mathrm{Fe}$ in the oceanic waters is strongly complexed by organic matter, which enhances the otherwise very low (0.1 nM) Fe solubility (Wu et al. 2001).
The hypothesis that an inadequate Fe supply is the major factor that controls phytoplankton production in HNLC areas of the open ocean (Martin et al. 1991) has been modified by this finding, and suggests that algal growth is limited not only by a general lack of $\mathrm{Fe}$ but also by its restricted availability. Therefore, Fe speciation is important for understanding the cycle of Fe among biotic and abiotic forms in marine systems.

During the recent Southern Ocean Iron Release Experiment (SOIREE), a marked increase in ligand concentrations towards the end of the experiment was observed and the dissolved Fe concentration remained high ( $>1 \mathrm{nM}$ ) (Croot et al. 2001). Moreover, the SOIREE bloom flourished for at least 55 days suggesting that a sufficient proportion of the added Fe was retained within the mixed layer (Abraham et al. 2000). Croot et al. (2001) speculate that the observed ligands provide the mechanism to maintain Fe in the surface ocean. The source of the ligands and their affinity for $\mathrm{Fe}$ is unknown, and how the Fe retention system is primed and then maintained raises fundamental questions about Fe cycling in HNLC polar waters.

In the present paper, we present the distribution and organic speciation of Fe along three surface seawater transects across a frontal zone, near the Chatham Rise, east of New Zealand. The location of New Zealand at the edge of the Southern Ocean provides a natural laboratory for studying ocean processes in a variety of oceanic conditions. The subtropical front (STF) is a dynamic region of enhanced 
Table 1. Hydrographic, nutrient and dissolved iron data

\begin{tabular}{|c|c|c|c|c|c|c|c|c|c|c|}
\hline $\begin{array}{l}\text { Station } \\
\text { ID }^{A}\end{array}$ & Latitude & Longitude & $\begin{array}{c}\text { Temperature } \\
\left({ }^{\circ} \mathrm{C}\right)\end{array}$ & Salinity & $\begin{array}{c}\mathrm{PO}_{4}^{3-} \\
\left(\mu \mathrm{mol} \mathrm{L}^{-1}\right)\end{array}$ & $\left.\begin{array}{c}\mathrm{Si} \\
(\mu \mathrm{mol} \mathrm{L} \\
-1\end{array}\right)$ & $\begin{array}{c}\text { Nitrate }+ \\
\text { nitrite } \\
\left(\mu \mathrm{mol} \mathrm{L}^{-1}\right)\end{array}$ & $\begin{array}{c}\mathrm{Fe}-\text { Otago }- \\
\text { GFAAS } \\
\text { (nM) }\end{array}$ & $\begin{array}{c}\mathrm{Fe}-\text { NIWA - } \\
\text { GFAAS } \\
\text { (nM) }\end{array}$ & $\begin{array}{c}\mathrm{Fe}-\mathrm{NIWA}- \\
\text { FI-CL } \\
\text { (nM) }\end{array}$ \\
\hline $11 \mathrm{~F}$ & $45^{\circ} 50.6^{\prime} \mathrm{S}$ & $171^{\circ} 33.4^{\prime} \mathrm{E}$ & 8.2 & 34.3 & 1.02 & 4.54 & 20.01 & 0.29 & - & - \\
\hline $12 \mathrm{~F}$ & $45^{\circ} 55.4^{\prime} \mathrm{S}$ & $172^{\circ} 27.8^{\prime} \mathrm{E}$ & 8.4 & 34.3 & 1.11 & 3.96 & 16.93 & 0.09 & - & - \\
\hline $13 \mathrm{~F}$ & $46^{\circ} 02.1^{\prime} \mathrm{S}$ & $173^{\circ} 32.7^{\prime} \mathrm{E}$ & 8.6 & 34.3 & 0.96 & 3.13 & 13.76 & 0.11 & - & - \\
\hline $14 \mathrm{~F}$ & $46^{\circ} 14.4^{\prime} \mathrm{S}$ & $175^{\circ} 48.9^{\prime} \mathrm{E}$ & 8.8 & 34.3 & 0.95 & 1.11 & 13.51 & 0.07 & - & - \\
\hline $16 \mathrm{~F}$ & $45^{\circ} 21.0^{\prime} \mathrm{S}$ & $178^{\circ} 29.8^{\prime} \mathrm{E}$ & 9.6 & 34.4 & 0.95 & 1.18 & 12.15 & 0.27 & 0.28 & 0.30 \\
\hline $17 \mathrm{~F}$ & $44^{\circ} 33.5^{\prime} \mathrm{S}$ & $178^{\circ} 36.0^{\prime} \mathrm{E}$ & 9.0 & 34.3 & 2.22 & 1.56 & 14.34 & 0.15 & 0.17 & 0.30 \\
\hline $18 \mathrm{~F}$ & $44^{\circ} 00.0^{\prime} \mathrm{S}$ & $178^{\circ} 29.4^{\prime} \mathrm{E}$ & 10.1 & 34.7 & 2.01 & 0.35 & 6.69 & 0.10 & 0.24 & 0.27 \\
\hline $19 \mathrm{~F}$ & $43^{\circ} 41.2^{\prime} \mathrm{S}$ & $178^{\circ} 30.1^{\prime} \mathrm{E}$ & 10.4 & 34.6 & 1.99 & $<0.07$ & 5.72 & 0.20 & 0.24 & 0.35 \\
\hline $20 \mathrm{~F}$ & $43^{\circ} 15.7^{\prime} \mathrm{S}$ & $178^{\circ} 29.3^{\prime} \mathrm{E}$ & 11.2 & 34.8 & 1.92 & $<0.07$ & 4.97 & 0.44 & 0.30 & 0.38 \\
\hline $21 \mathrm{~F}$ & $43^{\circ} 03.7^{\prime} \mathrm{S}$ & $179^{\circ} 29.5^{\prime} \mathrm{E}$ & 11.1 & 34.8 & 0.41 & $<0.07$ & 5.08 & 0.53 & 0.31 & 0.31 \\
\hline $22 \mathrm{~F}$ & $42^{\circ} 52.1^{\prime} \mathrm{S}$ & $178^{\circ} 29.8^{\prime} \mathrm{E}$ & 12.6 & 35.0 & 0.45 & 0.86 & 5.44 & 0.84 & 0.31 & 0.46 \\
\hline $23 \mathrm{~F}$ & $42^{\circ} 44.9^{\prime} \mathrm{S}$ & $178^{\circ} 29.8^{\prime} \mathrm{E}$ & 12.1 & 34.9 & 0.38 & $<0.07$ & 6.77 & 0.65 & 0.35 & 0.41 \\
\hline $24 \mathrm{~F}$ & $42^{\circ} 16.9^{\prime} \mathrm{S}$ & $178^{\circ} 31.2^{\prime} \mathrm{E}$ & 14.1 & 35.3 & 0.30 & 0.77 & 3.92 & 0.41 & 0.42 & 0.50 \\
\hline $25 \mathrm{~F}$ & $41^{\circ} 38.8^{\prime} \mathrm{S}$ & $178^{\circ} 30.7^{\prime} \mathrm{E}$ & 14.1 & 35.4 & 0.27 & 0.79 & 2.55 & 0.27 & 0.42 & 0.41 \\
\hline $26 \mathrm{~F}$ & $41^{\circ} 11.1^{\prime} \mathrm{S}$ & $178^{\circ} 28.9^{\prime} \mathrm{E}$ & 14.0 & 35.3 & 0.31 & 0.94 & 4.56 & 0.10 & 0.30 & 0.31 \\
\hline $27 \mathrm{~F}$ & $40^{\circ} 26.7^{\prime} \mathrm{S}$ & $178^{\circ} 09.5^{\prime} \mathrm{E}$ & 14.5 & 35.3 & 0.30 & 0.51 & 2.56 & 0.26 & - & - \\
\hline $28 \mathrm{~F}$ & $40^{\circ} 12.3^{\prime} \mathrm{S}$ & $177^{\circ} 50.4^{\prime} \mathrm{E}$ & 14.1 & 35.2 & 0.32 & 0.55 & 2.60 & 0.22 & - & - \\
\hline $30 \mathrm{~F}$ & $39^{\circ} 49.7^{\prime} \mathrm{S}$ & $177^{\circ} 20.0^{\prime} \mathrm{E}$ & 12.9 & 34.9 & 0.33 & 1.72 & 2.96 & 0.61 & - & - \\
\hline
\end{tabular}

GFAAS, Graphite furnace atomic absorption spectrometry. FI-CL, Flow injection chemiluminescence.

${ }^{\mathrm{A}}$ In the present stuty, the Otago transect covers sampling stations $11 \mathrm{~F}$ to $14 \mathrm{~F}$, the Hawkes Bay transect covers sampling stations $27 \mathrm{~F}$ to $30 \mathrm{~F}$, and the Chatham Rise transect covers sampling stations $16 \mathrm{~F}$ to $26 \mathrm{~F}$.

primary production (Bradford-Grieve et al. 1997; Boyd et al. 1999), where subtropical (ST) water mixes with subantarctic (SA) water forming the subtropical convergence (STC). The speciation measurements are compared with chlorophyll $a$ concentrations and the hydrography of the area.

\section{Materials and methods}

\section{Study area}

The study area is located east of the New Zealand landmass. Eighteen stations (Table 1) were sampled in austral spring (5-19 October 2000) on board the New Zealand Research Vessel Tangaroa (TAN0010 cruise). The voyage consisted of a section from Otago Peninsula east to $178^{\circ} 30^{\prime} \mathrm{E}$ (the Otago transect), then due north to $41^{\circ} \mathrm{S}$ (the Chatham Rise transect), then north-west to Cape Kidnappers (the Hawkes Bay transect) (Fig. 1).

Oceanic circulation south and east of New Zealand is strongly controlled by bathymetry (Heath 1985). The STC weaves northward along the shelf-break of the eastern South Island of New Zealand, where it is referred to as the Southland Current, before heading further east across the Chatham Rise. The STC appears to be topographically locked to this region where the seafloor rises sharply from a depth of $\sim 2300 \mathrm{~m}$ to 350 m (Heath 1985; Belkin and Gordon 1996). This dynamic region separates the southward-moving warm, saline, nutrient-depleted ST waters from the northward-moving cold, less saline, nutrient-replete SA waters. The macronutrient signatures of these two water masses are quite different. Subtropical waters are characteristically low in nitrate $\mathrm{NO}_{3}^{-}$, $0.7 \mu \mathrm{M})$, silicate $(\mathrm{Si}, 1.3 \mu \mathrm{M})$ and phosphate $\left(\mathrm{PO}_{4}^{3-}, 0.3 \mu \mathrm{M}\right)$, whereas the opposite is true of SA waters $\left(\mathrm{NO}_{3}^{-}, 18 \mu \mathrm{M} ; \mathrm{Si}, 4 \mu \mathrm{M}\right.$ and $\mathrm{PO}_{4}^{3-}$, $1.4 \mu \mathrm{M}$ ). The SA waters are HNLC in character (Bradford-Grieve et al. 1997; Boyd et al. 1999).

The major currents north of the STC are the East Cape Current (ECC) and the Wairarapa Eddy (WE) (Chiswell and Roemmich 1998). The ECC is a persistent southward flow, attached to the east coast of the North Island, and then joined by flow from the Southland Current. Part of the total flow is recirculated in the cyclonic eddy (WE), which is centred near $41^{\circ} \mathrm{S} 178^{\circ} 30^{\prime} \mathrm{E}$ and part flows away to the north-east (Chiswell 2000). The ECC itself retroflects near $42^{\circ} \mathrm{S}$ and then flows into and along the STC providing the northern source of subtropical water to the front.

\section{Sample collection and handling}

Surface seawater was collected by means of a modified towed steel torpedo-shaped 'fish' covered with metal-free, epoxy coating (Braungardt et al. 1998). The fish was deployed $\sim 6 \mathrm{~m}$ away from the hull to avoid contamination. The design of the $40 \mathrm{~kg}$ fish ensured that the sampling hose pointed forward and maintained a $\sim 1-2 \mathrm{~m}$ depth at speeds of 1-12 knots. Seawater samples were pumped continuously into a Class-100 clean air laboratory container using a peristaltic pump and polyethylene (PE) tubing. All sample tubing was thoroughly acidwashed before use $(10 \% \mathrm{HCl})$. Sub-samples were taken by filling acid-cleaned 500-mL PE bottles (Nalgene, Rochester, NY) following on-line filtration through acid-cleaned Sartobran-P capsules $(0.45 \mu \mathrm{m}$ prefilter, $0.2 \mu \mathrm{m}$ final filter; Sartorius, Göttingen, Germany). Samples for speciation measurements were then double bagged and quickly frozen at $-20^{\circ} \mathrm{C}$. They were transported frozen to the laboratory and only thawed immediately before analysis.

\section{Macronutrients and conductivity-temperature-depth}

Temperature and salinity were measured with a Sea-Bird conductivitytemperature-depth meter (CTD; Sea-Bird Electronics, Bellevue, WA). Macronutrients were determined immediately after collection on single aliquots of filtered samples using an Astoria Analyzer 300 series autoanalyzer (Astoria-Pacific International, Clackamas, OR). Dissolved reactive phosphorus was determined by the autoanalytical method of Downes (1978) modified by eliminating the reductant. Silicic acid was determined using the method of Smith and Milne (1981), and nitrite 


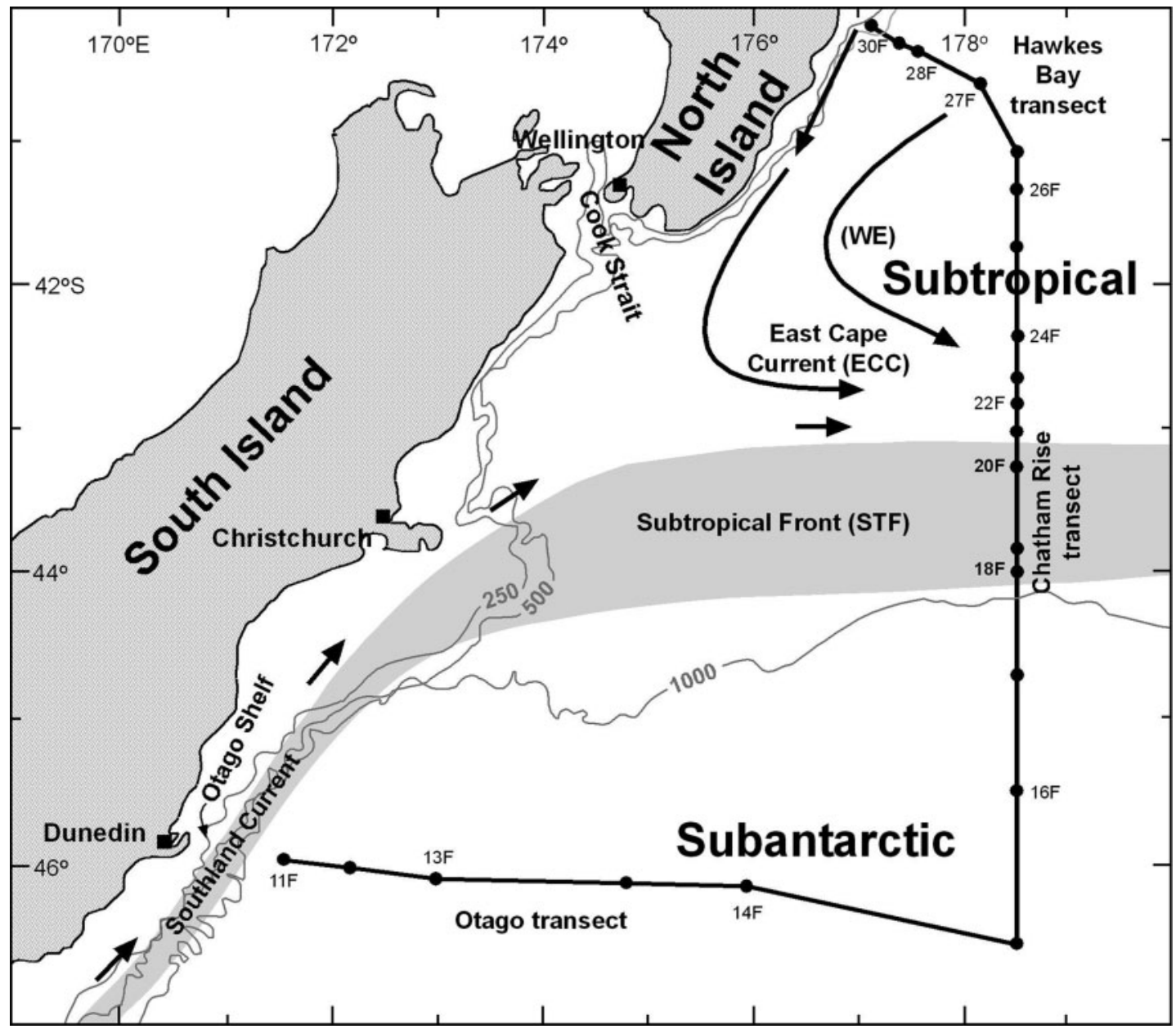

Fig. 1. Location map showing the sampling stations, surface water masses and surface circulation patterns, relative to the Chatham Rise.

plus nitrate were determined using the method developed by Nydahl (1976).

Duplicate chlorophyll $a$ (chl a) samples were collected on GF/F filters and folded into aluminum foil and immediately frozen. Ashore, chl $a$ was extracted into $90 \%$ acetone and determined by fluorometry (Strickland and Parsons 1972).

\section{Total dissolved iron determinations}

Total dissolved $\mathrm{Fe}$ was concentrated from the acidified samples in the Otago laboratory using an ammonium-pyrrolidine-dithiocarbamate (APDC)/diethyl-ammonium-diethyldithio-carbamate (DDDC) chelation/solvent extraction technique, adapted from that of Danielsson et al. (1982) by substituting chloroform for Freon-11 as the extracting solvent as described in detail by Frew and Hunter (1995) and Frew et al. (2001). The sample aliquot to be extracted was generally $150 \mathrm{~g}$ and duplicate aliquots were analysed from each sample. Fe in the extracts was determined by graphite furnace atomic absorption spectrometry (GFAAS, PE 4100 ZL; Perkin-Elmer, Wellesley, MA). Recovery efficiencies were determined by standard addition analysis of previously extracted seawater and blanks were determined by analysing Milli-Q water (Millipore, Billerica, MA) or previously extracted seawater. Extraction efficiencies were $90 \pm 4 \%$, blanks were $<0.03 \mathrm{~nm}$, and the detection limit was $0.05 \mathrm{~nm}(2 \sigma)$. Standard operating conditions, including Zeeman background correction, were used.
In addition, duplicate samples from the Chatham Rise transect were analysed by a similar solvent extraction/GFAAS method at NIWA, Hamilton. The NIWA samples were also analysed by chemiluminescence using the Obata method (Obata et al. 1993). A comparison of Otago and NIWA results is presented in Table 1.

\section{Cathodic stripping voltammetry iron speciation determinations}

Organic complexation of $\mathrm{Fe}$ was determined by competitive ligand exchange-adsorptive cathodic stripping voltammetry (CSV) with ligand competition against 2-(2-thiazolylazo)-p-cresol (TAC) (Croot and Johansson 2000).

The voltammetry equipment consisted of a Metrohm VA 663 stand (Herisau, Switzerland), with a multi-mode electrode and a $\mu$ autolab type II potentiostat (Eco Chemie, Utrecht, The Netherlands). The working electrode was a hanging mercury drop electrode (HMDE) with a 'medium' mercury drop $\left(0.4 \mathrm{~mm}^{2} \pm 10 \%\right)$, the reference electrode was double-junction $\mathrm{Ag}$ /saturated $\mathrm{AgCl}$ electrode with a salt bridge filled with $3 \mathrm{M} \mathrm{KCl}$ and the counter electrode was glassy carbon. During the CSV analyses, all samples were contained in Teflon sample cups (Metrohm), and stirred with the inbuilt PTFE Teflon stirring tip $(1500 \mathrm{rpm})$ of the VA 663.

Subsamples $(10 \mathrm{~mL})$ of seawater were pipetted into a series of 12 Teflon bottles and buffered at $\mathrm{pH} 8.0$ with $1.0 \mathrm{M}$ stock buffer of EPPS ( $N$-(2-hydroxyethyl)-piperazine- $N^{\prime}-2$-propanesulfonic acid; 
Sigma-Aldrich, St Louis, MO). Iron spikes were added to all but two of the bottles, yielding concentrations from 0 to $4 \mathrm{~nm}$. The added Fe was allowed to equilibrate with the natural ligands for $1 \mathrm{~h}$ at room temperature. After this equilibration period, $10 \mu \mathrm{L}$ of $10 \mathrm{~mm}$ methanolic TAC solution was added and the sample left to equilibrate for at least $5 \mathrm{~h}$ (often overnight, $15-18 \mathrm{~h}$ ). The equilibrated solutions were then sequentially (starting from the lowest concentration) transferred to the Teflon cell cup. Each solution was de-aerated for $4 \mathrm{~min}$ with oxygen-free nitrogen gas. A fresh $\mathrm{Hg}$ drop was made, and $\mathrm{Fe}(\mathrm{TAC})_{2}$ complex species were adsorbed at an applied potential of $-0.4 \mathrm{~V}$ for $120 \mathrm{~s}$, while stirring at $1500 \mathrm{rpm}$. The stirrer was switched off for a 5-s quiescence period; thereafter the potential was scanned in the differential pulse mode from -0.38 to $-0.65 \mathrm{~V}$ at $2.55 \mathrm{mV} \mathrm{s}^{-1}$ (pulse amplitude $49.95 \mathrm{mV}$ ) and the cathodic stripping current from adsorbed $\mathrm{Fe}(\mathrm{TAC})_{2}$ recorded. Cell cups were rinsed with Milli-Q water between analyses. Each Teflon bottle was consistently used for a particular Fe addition.

\section{Calculation of the iron speciation}

Measurements of Fe organic speciation using electrochemical methods focus primarily on determining the strength of Fe-binding ligands in seawater (the conditional stability constant, $K_{\mathrm{FeL}}^{\prime}$ ), and the concentration of total naturally occurring organic Fe-binding ligands $\left(L_{\mathrm{T}}\right)$. The theoretical basis of the calculation of ligand concentration from titration data for labile metal concentration was introduced by Ruzic (1982), van den Berg (1982) and in the specific case for Fe by Gledhill and van den Berg (1994), and Rue and Bruland (1995). In the present study, the total ligand concentrations $\left[L_{\mathrm{T}}\right]$ and the conditional stability constants $K_{\mathrm{FeL}}^{\prime}$ for the formation of the Fe-ligand were calculated by performing a nonlinear least-squares fitting algorithm of the data fitted to the following equation (Gerringa et al. 1995):

$$
[\mathrm{FeL}]=\frac{\left[L_{\mathrm{T}}\right] K_{\mathrm{FeL}}^{\prime}\left[\mathrm{Fe}^{\prime}\right]}{1+K_{\mathrm{FeL}}^{\prime}\left[\mathrm{Fe}^{\prime}\right]}
$$

where $[\mathrm{FeL}]$ represents the organically-bound fraction of the Fe-binding ligands and $\left[\mathrm{Fe}^{\prime}\right]$ is the sum of all the inorganic species. $K_{\mathrm{FeL}}^{\prime}$ is the conditional stability constant with respect to $\mathrm{Fe}^{\prime}$ under these conditions (in this case $\mathrm{pH} 8.0$ seawater). To convert $K_{\mathrm{FeL}}^{\prime}$ to $K_{\mathrm{FeL}, \mathrm{Fe}^{3+}}^{\prime}$, the conditional stability constant for FeL with respect to free $\mathrm{Fe}^{3+}$, the relationship between $\mathrm{Fe}^{\prime}$ and $\mathrm{Fe}^{3+}, \alpha_{\mathrm{Fe}}^{\prime}=\left[\mathrm{Fe}^{\prime}\right] /\left[\mathrm{Fe}^{3+}\right]$, can be used:

$$
K_{\mathrm{FeL}, \mathrm{Fe}^{3+}}^{\prime}=\alpha_{\mathrm{Fe}}^{\prime} K_{\mathrm{FeL}}^{\prime}
$$

Here $\alpha_{\mathrm{Fe}}^{\prime}$ of $10^{10.0}$ from the work of Hudson et al. (1992) is used. $\left[\mathrm{Fe}^{\prime}\right]$ is related to the Fe reduction peak current $\left(I_{\mathrm{P}}\right)$ by the following relationship:

$$
\left[\mathrm{Fe}^{\prime}\right]=\frac{I_{\mathrm{P}}}{S \alpha_{\mathrm{Fe}(\mathrm{TAC})_{2}}}
$$

where $S$ is the analytical sensitivity. Previously $S$ was determined from the linear region at the high $\mathrm{Fe}$ end of the titration, a method that is somewhat prone to errors of judgment and leads to an underestimation of $S$ and $L_{\mathrm{T}}$. Correction of $S$ by modelling has been made before (Turoczy and Sherwood 1997; Hudson et al. 2003; van den Berg 2006) and a similar iterative procedure is used in the present study. The side reaction coefficient for $\mathrm{Fe}(\mathrm{TAC})_{2}$ is denoted by $\alpha_{\mathrm{Fe}(\mathrm{TAC})_{2}}$ with a value of 250 (Croot and Johansson 2000).

Speciation data was calculated for $K_{\mathrm{FeL}}^{\prime}$ and $L_{\mathrm{T}}$ using the Gerringa non-linear regression fitted for a single ligand model. The standard deviations of $K_{\mathrm{FeL}}^{\prime}$ and $L_{\mathrm{T}}$ were calculated from non-linear leastsquares regression of the titration curves using the computer program NLREG (www.nlreg.com/, verified June 2006). Errors were reported for $95 \%$ confidence intervals. The ambient $\left[\mathrm{Fe}^{\prime}\right]$ was estimated by solving Eqn (1), using the calculated values of $K_{\mathrm{FeL}}^{\prime}$ and $L_{\mathrm{T}}$ at the ambient dissolved $\mathrm{Fe}$ concentration. The concentration of FeL can thus be calculated from:

$$
[\mathrm{FeL}]=[\mathrm{Fe}]-\left[\mathrm{Fe}^{\prime}\right]
$$

where $[\mathrm{Fe}]$ is the total dissolved Fe concentration. So the percentage of Fe occurring as organic species is calculated from:

$$
[\mathrm{FeL}] \%=\frac{[\mathrm{FeL}]}{[\mathrm{Fe}]} \times 100 \%
$$

\section{Results}

\section{Nutrient, chlorophyll a and hydrographic data}

Nutrient and hydrographic data associated with each sampling station are presented in Table 1. The Chatham Rise transect crossed two main water masses separated by a frontal boundary (Fig. 1), which are described by the temperaturesalinity (T-S) properties of warm, salty ST waters $\left(\mathrm{T}=14^{\circ} \mathrm{C}\right.$, $\mathrm{S}=35.4$ ), intermediate salinity STC waters, and cold, less saline SA waters $\left(\mathrm{T}=8.5^{\circ} \mathrm{C}, \mathrm{S}=34.3\right)$ (Fig. 2). Macronutrient concentrations were generally higher in SA waters $\left(\mathrm{NO}_{3}^{-}, 14-20 \mu \mathrm{M} ; \mathrm{Si}, 1.5-4.5 \mu \mathrm{M}\right.$ and $\left.\mathrm{PO}_{4}^{3-}, 1-2.2 \mu \mathrm{M}\right)$ than in STC or ST waters $\left(\mathrm{NO}_{3}^{-}, 2-6 \mu \mathrm{M} ; \mathrm{Si}, \sim 0.7 \mu \mathrm{M}\right.$ and $\mathrm{PO}_{4}^{3-}$, $\sim 0.35 \mu \mathrm{M})$ (Figs 2, 3; Table 1).

Chlorophyll $a$ concentrations remained relatively constant, with values ranging between 0.08 and $0.24 \mathrm{mg} \mathrm{m}^{-3}$ along the Otago transect. Chlorophyll $a$ increased sharply to $\sim 0.75 \mathrm{mg} \mathrm{m}^{-3}$ on the Chatham Rise and then decreased to $\sim 0.4 \mathrm{mg} \mathrm{m}^{-3}$ at $41^{\circ} \mathrm{S}$. Along the Hawkes Bay transect, chl $a$ concentrations ranged between 0.72 and $0.89 \mathrm{mg} \mathrm{m}^{-3}$ (Fig. 3).

On the Chatham Rise, Si concentrations dropped below the detection limit $(0.07 \mu \mathrm{M})$ accompanied by the high chl $a$ concentrations, suggesting significant $\mathrm{Si}$ utilisation by the phytoplankton community.

\section{Dissolved iron and iron-binding ligands in three surface transects}

The results of the organic speciation work along the three surface transects are shown in Fig. 3, collated in Table 2. Low dissolved $\mathrm{Fe}$ concentrations were observed in the SA waters and remained relatively constant at $\sim 0.1 \mathrm{~nm}$. Along Hawkes Bay, the dissolved Fe concentration was high $(\sim 0.6 \mathrm{nM})$ in the surface water above the continental shelf, then decreased to $\sim 0.3 \mathrm{~nm}$ in a south-easterly direction (offshore).

For the Chatham Rise transect, the dissolved Fe concentrations showed a different pattern, in which elevated dissolved Fe concentrations were up to $0.8 \mathrm{~nm}$ at the north flank of the Chatham Rise, then decreased to $\sim 0.1 \mathrm{~nm}$ both northward and southward.

Along with the dissolved Fe concentrations, the average concentration of total organic-complexing ligands was 

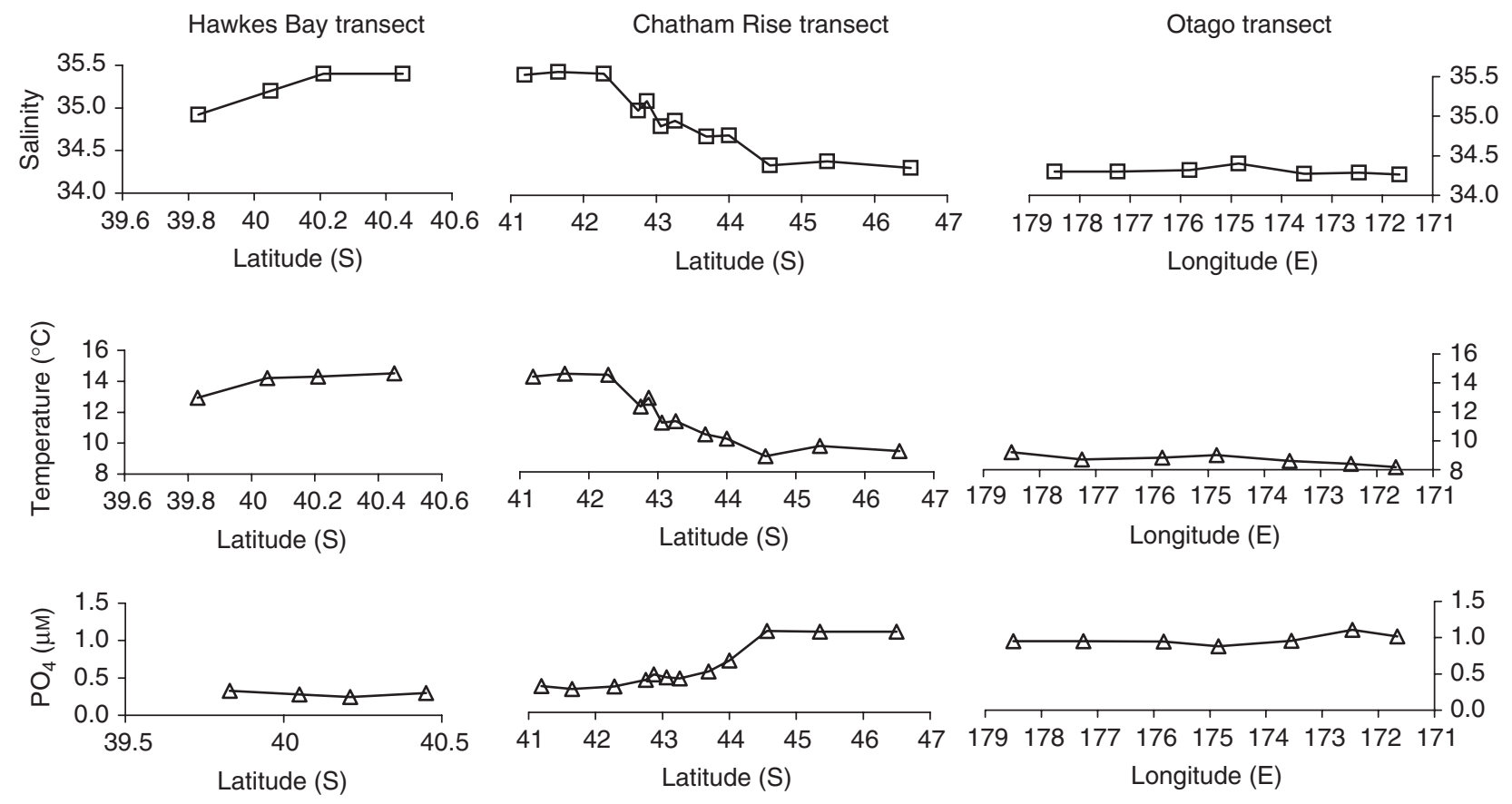

Fig. 2. Transects showing salinity, temperature and $\mathrm{PO}_{4}^{3-}$ concentrations.
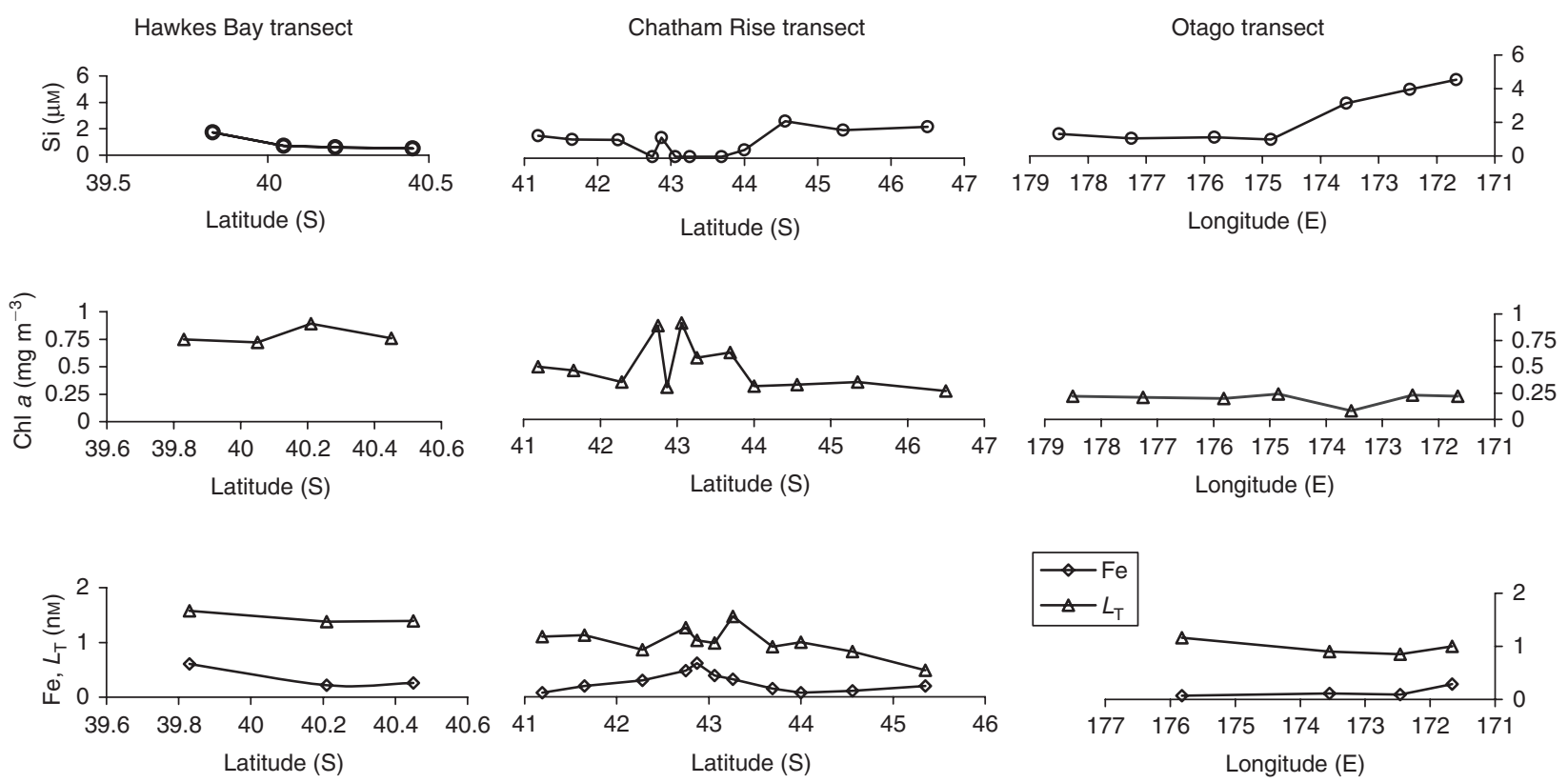

Fig. 3. Concentrations of silicon, chlorophyll $a$, dissolved iron and ligands along the three transects.

$1.29 \pm 0.33 \mathrm{~nm}(n=18)$. There was a difference between the concentration for the SA waters and the ST waters $\left(L_{\mathrm{T}}\right.$ values of $0.95 \pm 0.19 \mathrm{~nm}$ and $1.43 \pm 0.15 \mathrm{~nm}$ respectively). 'Excess' ligand concentration is defined as the concentration of total Fe-binding ligand minus the concentration of total dissolved
Fe at each measured station. The average 'excess' ligand concentration was $0.98 \pm 0.30 \mathrm{~nm}(n=18$, Table 2$)$.

Estimated values of $\mathrm{Fe}^{\prime}$ ranged from $\sim 0.01$ to $0.2 \mathrm{pm}$ with slightly elevated $\mathrm{Fe}^{\prime}$ over the Chatham Rise transect. There was no systematic change in the conditional stability constant 
Table 2. Iron speciation data along the three surface transects

\begin{tabular}{lccccc}
\hline $\begin{array}{l}\text { Station } \\
\text { ID }\end{array}$ & $\begin{array}{c}\text { Total dissolved Fe- } \\
\text { binding ligand } L_{\mathrm{T}}(\mathrm{nM})\end{array}$ & Log $K_{\mathrm{FeL}, \mathrm{Fe}^{3+}}^{\prime}$ & $\begin{array}{c}\text { 'Excess' Fe-binding } \\
\text { ligand }\left(L_{\mathrm{T}}-\mathrm{Fe}, \mathrm{nM}\right)\end{array}$ & $\begin{array}{c}\mathrm{Fe}^{\prime} \\
(\mathrm{pM})\end{array}$ & $\begin{array}{c}\mathrm{FeL} \\
(\%)\end{array}$ \\
\hline $11 \mathrm{~F}$ & $1.00 \pm 0.06$ & $22.82 \pm 0.18$ & 0.71 & 0.06 & 99.98 \\
$12 \mathrm{~F}$ & $0.85 \pm 0.09$ & $22.85 \pm 0.24$ & 0.76 & 0.02 & 99.98 \\
$13 \mathrm{~F}$ & $0.90 \pm 0.08$ & $22.54 \pm 0.20$ & 0.79 & 0.04 & 99.96 \\
$14 \mathrm{~F}$ & $1.16 \pm 0.15$ & $22.92 \pm 0.32$ & 1.09 & 0.01 & 99.98 \\
$16 \mathrm{~F}$ & $0.66 \pm 0.08$ & $22.69 \pm 0.28$ & 0.39 & 0.14 & 99.95 \\
$17 \mathrm{~F}$ & $1.12 \pm 0.08$ & $22.35 \pm 0.20$ & 0.97 & 0.07 & 99.95 \\
$18 \mathrm{~F}$ & $1.36 \pm 0.09$ & $22.47 \pm 0.14$ & 1.26 & 0.03 & 99.97 \\
$19 \mathrm{~F}$ & $1.24 \pm 0.05$ & $22.44 \pm 0.08$ & 1.04 & 0.07 & 99.97 \\
$20 \mathrm{~F}$ & $2.00 \pm 0.16$ & $22.57 \pm 0.24$ & 1.56 & 0.08 & 99.98 \\
$21 \mathrm{~F}$ & $1.34 \pm 0.09$ & $22.61 \pm 0.18$ & 0.81 & 0.16 & 99.97 \\
$22 \mathrm{~F}$ & $1.40 \pm 0.20$ & $23.02 \pm 0.56$ & 0.56 & 0.14 & 99.98 \\
$23 \mathrm{~F}$ & $1.72 \pm 0.16$ & $22.68 \pm 0.18$ & 1.07 & 0.13 & 99.98 \\
$24 \mathrm{~F}$ & $1.17 \pm 0.18$ & $22.75 \pm 0.40$ & 0.76 & 0.10 & 99.98 \\
$25 \mathrm{~F}$ & $1.53 \pm 0.16$ & $22.78 \pm 0.18$ & 1.26 & 0.04 & 99.99 \\
$26 \mathrm{~F}$ & $1.50 \pm 0.26$ & $22.23 \pm 0.30$ & 1.40 & 0.04 & 99.96 \\
$27 \mathrm{~F}$ & $1.39 \pm 0.14$ & $22.74 \pm 0.22$ & 1.13 & 0.04 & 99.98 \\
$28 \mathrm{~F}$ & $1.38 \pm 0.16$ & $22.56 \pm 0.34$ & 1.16 & 0.05 & 99.98 \\
$30 \mathrm{~F}$ & $1.58 \pm 0.20$ & $23.05 \pm 0.30$ & 0.97 & 0.06 & 99.99 \\
\hline
\end{tabular}

${ }^{A}$ In our calculation, the subtropical waters include stations $24 \mathrm{~F}$ to $30 \mathrm{~F}$, the SA waters include stations $11 \mathrm{~F}$ to $17 \mathrm{~F}$, and the subtropical convergence waters include stations $18 \mathrm{~F}$ to $23 \mathrm{~F}$.

$\left(K_{\mathrm{FeL} F \mathrm{Fe}^{3+}}^{\prime}\right.$, with respect to $\left.\mathrm{Fe}^{3+}\right)$. The values varied from $10^{22.23}$ to $10^{23.05}$ (mean \pm s.d. $=10^{22.67 \pm 0.22}$ ).

\section{Discussion}

\section{Dissolved iron}

There are very few attempts at analytical intercomparison for trace metals reported to date. Although a tremendous amount has been learnt about the distribution and biogeochemistry of Fe in recent years, the ability to relate one study to another remains problematic. The most recent international analytical intercomparison study (Bowie et al. 2006) showed that different analytical methods give significantly different dissolved Fe concentrations. Moreover, Bowie et al. (2006) highlighted the variability in reported $\mathrm{Fe}$ concentrations even when the same analytical methods were used. The coefficient of variation for the GFAAS methodology was close to $50 \%$.

The Otago and NIWA results from the present study generally agree well with no systematic trend in differences. The Otago results show a maximum at station $22 \mathrm{~F}$ (Fig. 4) that is not apparent in the NIWA data and the possibility of contamination cannot be excluded. However, this point coincides with local maxima in nutrient concentrations $\left(\mathrm{PO}_{4}^{3-}\right.$ and $\mathrm{Si}$, Table 1) and the variation between Fe results is still only 50\%, similar to the expected level of variability for this technique (Bowie et al. 2006). We used the Otago dataset for interpretation of CSV titration results because it is the only full Fe dataset available in the present study.

The dissolved Fe concentrations found in the SA and ST surface waters (from $\sim 0.1 \mathrm{nM}$ along the Otago transect to $\sim 0.3 \mathrm{~nm}$ along the Hawkes Bay transect) are comparable with

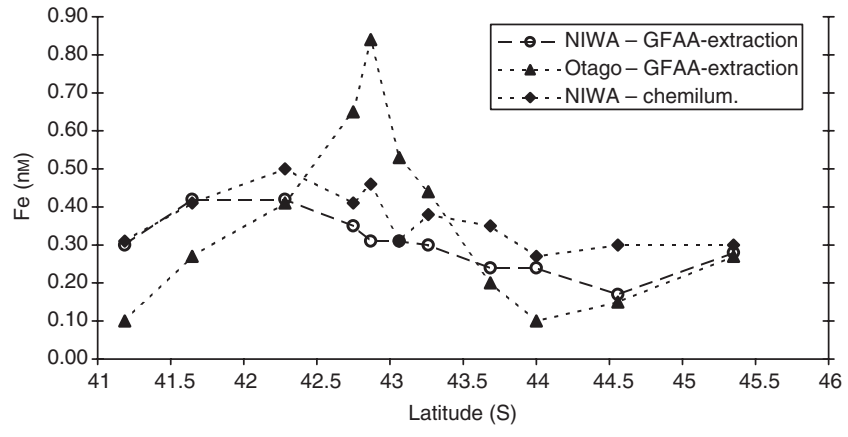

Fig. 4. Comparison of three different dissolved Fe datasets for surface waters along the Chatham Rise transect.

those in surface waters in the Southern Ocean $(\sim 0.1 \mathrm{~nm}$ (Sedwick et al. 1997; Bowie et al. 2001) to $\sim 0.6 \mathrm{~nm}$ (de Jong et al. 1999)). The highest concentration was found just north of the Chatham Rise (0.8 nM, Station 22F).

The higher Fe concentration $(\sim 0.6 \mathrm{~nm})$ found in the Hawkes Bay transect is probably related to the proximity of landmasses to the $\mathrm{ST}$ water - maxima in $\mathrm{T}, \mathrm{S}$ and macronutrient concentrations are also observed at station 22F, suggesting the importance of physical transport mechanisms. The T-S properties of this water (Fig. 5) indicate it has a subtropical source and is likely from the East Cape Current. This indicates the ECC is a significant source of dissolved Fe for the STC.

River run-off from the New Zealand landmass tends to increase Fe concentration in ST water rather than SA water because the Subtropical Front and Southland Front always lie south of the South Island, which prevents a classical 'island 


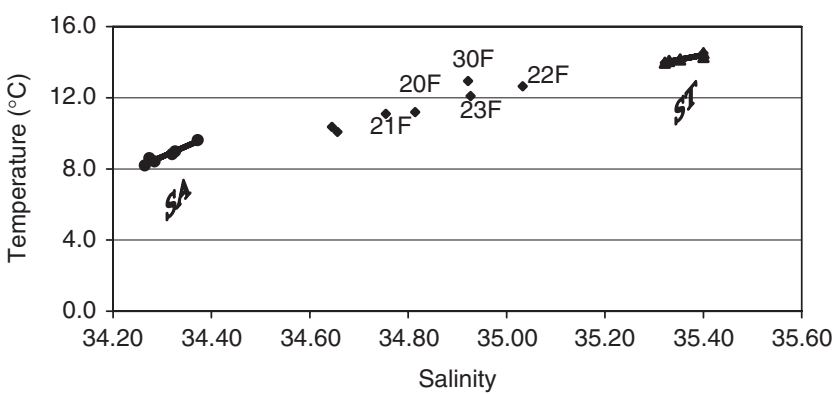

Fig. 5. Temperature-salinity $(\mathrm{T}-\mathrm{S})$ diagram for surface waters along the three transects.

wake effect' (Boyd et al. 1999; Signorini et al. 1999). A previous study showed the surface concentrations of Fe decreased dramatically across the Otago shelf (Croot and Hunter 1998). It appears that the Southern Current acts to control the flux of Fe across the shelf by transporting materials rapidly along the shelf further north. Furthermore, the role of atmospheric deposition in the supply of Fe to the study area is at present uncertain (Boyd et al. 2004b). A recent atmospheric Fe deposition flux study in the eastern Atlantic Ocean suggested that wet deposition dominated in the intertropical convergence zone, whereas dry deposition dominated in the other regions of the transect, where rainfall rates were much lower (Sarthou et al. 2003).

The sampling station with the highest dissolved Fe concentration is located at $42^{\circ} 52^{\prime} \mathrm{S}$, coincident with the location where the ECC is mixing with the STC. It has been suggested (Garner 1959) that the transport of subtropical water by the ECC into the STC is important in maintaining the convergence over the Chatham Rise. Thus, our Fe data may imply that the regional currents (e.g. ECC) could be an important vehicle for carrying the elevated $\mathrm{Fe}$ from the coastal waters to the north flank of the Chatham Rise, which may then trigger phytoplankton growth. The relatively high primary productivity within the STF over the Chatham Rise likely arises because the front provides a regime with both sufficient macronutrient and micronutrient $(\mathrm{Fe})$ to drive primary production. The possibility that mesoscale eddies could play a role in nutrient supply to the upper ocean has been suggested by several researchers (Franks et al. 1986; Falkowski et al. 1991).

\section{The organic iron-binding ligands}

A representative titration of the ligands is shown in Fig. 6, which shows the peak height (representing labile Fe) versus the total Fe added. The CSV titration with Fe showed clear Fe-binding at low Fe additions to all samples, indicating the presence of excess organic Fe-binding ligands. All data presented in the present work have been calculated assuming only one class of Fe-binding ligand.

Results from the surface transects show that the total Fe-binding ligand concentrations are consistently higher $(\sim 0.5 \mathrm{nM})$ in the ST and STC waters $(1.47 \pm 0.22 \mathrm{nM}, n=12)$ than in the SA waters $(0.95 \pm 0.19 \mathrm{~nm}, n=6)$. 'Excess' ligands represent the portion of ligands in excess of the total dissolved $\mathrm{Fe}$ and available to complex any new $\mathrm{Fe}$ that enters the system. Again, a similar trend is observed that the mean 'excess' ligand concentration in the ST and STC waters is $\sim 0.3 \mathrm{~nm}$ higher than the mean concentration in the SA waters. We also performed the speciation calculation using both Otago and NIWA dissolved Fe data from the Chatham Rise transect. Because the total ligand is in excess of total $\mathrm{Fe}$, using the NIWA Fe data alters the total ligand concentration by $0.1-0.2 \mathrm{~nm}$. Only at station $22 \mathrm{~F}$ is a higher difference observed $(0.4 \mathrm{nM})$. Despite the discrepancies between different $\mathrm{Fe}$ datasets, differences in calculated ligand concentrations using either one are small.

Organic Fe speciation measurements (Table 3) have been reported from different oceanic regimes. Despite differences in the choice of CSV approaches used by various research groups, one common finding is the presence of the excess Fe-binding ligands in the world's oceans, ranging from $\sim 1$ to $\sim 10 \mathrm{~nm}$. Their conditional stability constants range in magnitude between 18 and 23. The ligand concentrations and their conditional stability constants in the present study are comparable with those found in the Atlantic sector of the Southern Ocean (Boye et al. 2001), the central gyre of the North Pacific (Rue and Bruland 1995) and the Arabian Sea (Witter et al. $2000 a$ ).

Rue and Bruland (1995) observed the presence of two classes of ligands in the Central North Pacific. The absence of curvature in the linearised titration data of our study suggests that Fe complexation in our water samples is consistent with the single ligand model. There is no evidence for the presence of two classes of ligands. However, the linearity of the titration curves does not exclude the existence of weak ligands in excess of $\mathrm{Fe}(\mathrm{III})$ in the samples. The detection window of a CSV method is determined by the balance of the relative stabilities of the natural complex and the complexes formed with the added ligand. According to van den Berg and Donat (1992), no Fe is detected if the natural complex is much more stable than the complex with the added ligand, whereas no complexation is detected if the natural organic complex is much weaker than the complex with added ligand and is outcompeted by the added ligand. The competing ligand (TAC) used in our study has a detection window (centred by $\alpha_{\mathrm{Fe}(\mathrm{TAC})_{2}}$ and within one order of magnitude on either side) between $10^{11.4}$ and $10^{13.4}$, which is higher than the ligand (Salicylaldoxime) used for the Pacific studies (Rue and Bruland 1995, 1997). It is therefore possible that excess weak ligands with a $\alpha_{\mathrm{FeL}}<10^{11.4}$ would not have been detected in our titrations. Thus, the choice of analytical competition strength employed can bias the estimates of both ligand concentrations and conditional stability constants.

The conditional stability constant with respect to $\mathrm{Fe}^{3+}$ depends on the assumption of the inorganic side reaction coefficient. There is still some debate regarding the existence 
(a)

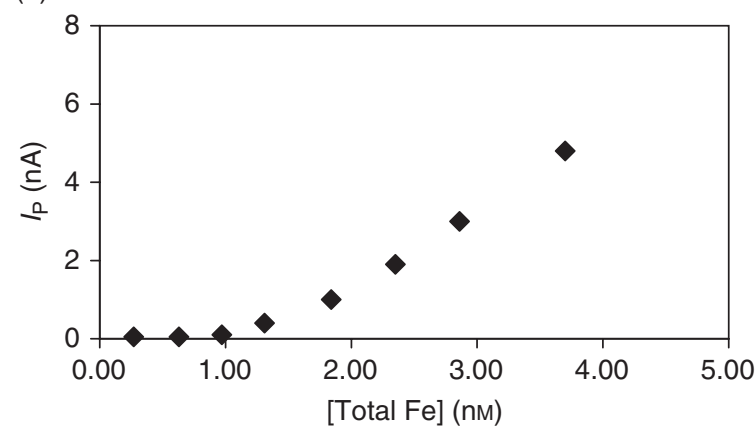

(b)

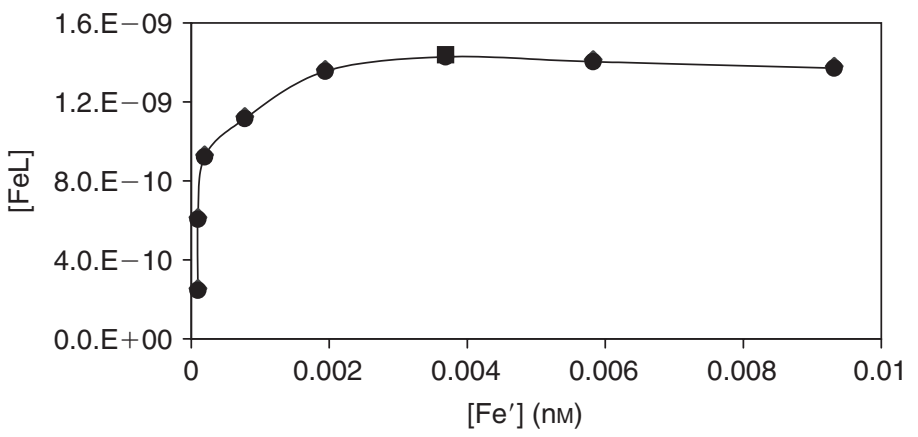

Fig. 6. Representative titration curve for surface seawater sample from station $25 \mathrm{~F}$ : $(a)$ current (nA) is plotted versus total amount of Fe; and (b) non-linear least-squares fit using Gerringa method.

of various inorganic $\mathrm{Fe}(\mathrm{III})$ species, especially $\mathrm{Fe}(\mathrm{OH})_{3}^{0}$. Likewise, the value of the $\alpha_{\mathrm{Fe}}^{\prime}$ used by different researchers varies from $10^{8.5}$ to $10^{11.9}$. It is therefore better to use the organic $\alpha$ coefficient $\left(\alpha_{\mathrm{FeL}}\right.$, product of conditional stability constant $K_{\mathrm{FeL}, \mathrm{Fe}^{3+}}^{\prime}$ and the ligand concentration $L_{\mathrm{T}}$, the binding potential of the organic ligands) when comparing results with work by others (Table 3 ).

The relative constancy of the conditional stability constants $\left(\log K_{\mathrm{FeL}, \mathrm{Fe}^{3+}}^{\prime}=22.67 \pm 0.22\right)$ determined in the present study is still not able to rule out the presence of different types of ligands across the water masses. Witter et al. (2000a) argue that the CSV method cannot distinguish between different organic moieties that may be present in seawater, because the measured conditional stability constants do not vary in a systematic manner with Fe-binding ligand structure. Moreover, results from the surface transects show that the total $\mathrm{Fe}$-binding ligand concentrations are consistently higher $(\sim 0.5 \mathrm{nM})$ in the ST and STC waters than in the SA waters.

The biological purpose of the organic ligands in the oceans is not yet fully understood. Possibilities are that the ligands may serve to buffer trace metal activities within the physiological tolerance range for microorganisms, or limit the scavenging loss of bioactive metals to sinking particles. It is perhaps interesting to ask why the excess ligand concentrations are slightly higher in the ST and STC waters. Is this phenomenon linked to the local planktonic community structure, the biological sources of the ligands, or the biological and abiotic reactions in the water? There was no clear evidence available from the present study. However, the parallel increase in the ligand and $\mathrm{Fe}$ concentrations, along with increases in the chlorophyll $a$ concentration, may suggest that the ligand concentrations were increased by microorganisms in response to the increased overall Fe concentration or that there was simply more cells and hence more ligands.

Previous research in this study area showed that in spring, SA phytoplankton populations were dominated by eukaryotic picophytoplankton and diatoms had a relatively low biomass (Chang and Gall 1998). Bacterial production was strongly correlated with chlorophyll $a$ and primary production (Smith and Hall 1997). Heterotrophic bacteria made a large contribution to total community biomass and the bacterial biomass was almost double in the ST waters than in the SA waters. The results from Smith and Hall's study suggest that in New Zealand oceanic water masses bacteria are of significant biogeochemical importance. It is therefore likely that the bacteria may contribute positively to the discrepancy in the ligand concentrations between the ST and SA waters found in the present study.

\section{Iron availability}

It has not yet been possible to define which forms of Fe (organic complex Fe(III), inorganic Fe(III), Fe(III) or particulate $\mathrm{Fe}$ ) are more bioavailable. At the end of the SOIREE experiment, $\mathrm{Fe}(\mathrm{II})$ appeared to comprise the major portion of dissolved Fe species (Croot et al. 2001), implying a previously unheralded importance for Fe(II) and organic complexation in the Southern Ocean. However, the CSV method used in the present study is not able to measure the redox speciation ( $\mathrm{Fe}(\mathrm{II}) / \mathrm{Fe}(\mathrm{III})$ ).

A previous study in the same frontal zone (Boyd et al. 1999) showed that primary production was dominated by cells $<2 \mu \mathrm{m}$ (cyanobacteria) in SA waters. In contrast, STC and ST waters had higher algal biomass/production levels. In vitro $\mathrm{Fe}$ enrichment incubations in SA waters indicated the alleviation of $\mathrm{Fe}$ stress, also the iron-mediated increases in chlorophyll $a$ (in particular, increases in large diatoms). In spring, irradiance and Fe may both control diatom growth, whereas during summer, as mean irradiance increases and silicate concentrations decrease, Fe limitation, $\mathrm{Fe} / \mathrm{Si}$ colimitation, or silicate limitation may constrain diatom growth.

Calculation of the chemical speciation based on the thermodynamic equilibrium shows that $\mathrm{Fe}$ is fully ( $>99.9 \%$ ) complexed by organic ligands throughout the waters studied. The ratio of organic/combined inorganic $\mathrm{Fe}$ $\left(\mathrm{FeL} /\left[\mathrm{Fe}^{\prime}\right]=\alpha_{\mathrm{FeL}} / \alpha_{\mathrm{Fe}^{\prime}}\right)$ is $10^{3.8}$, which means the inorganic dissolved $\mathrm{Fe}$ concentrations are on average over three orders 


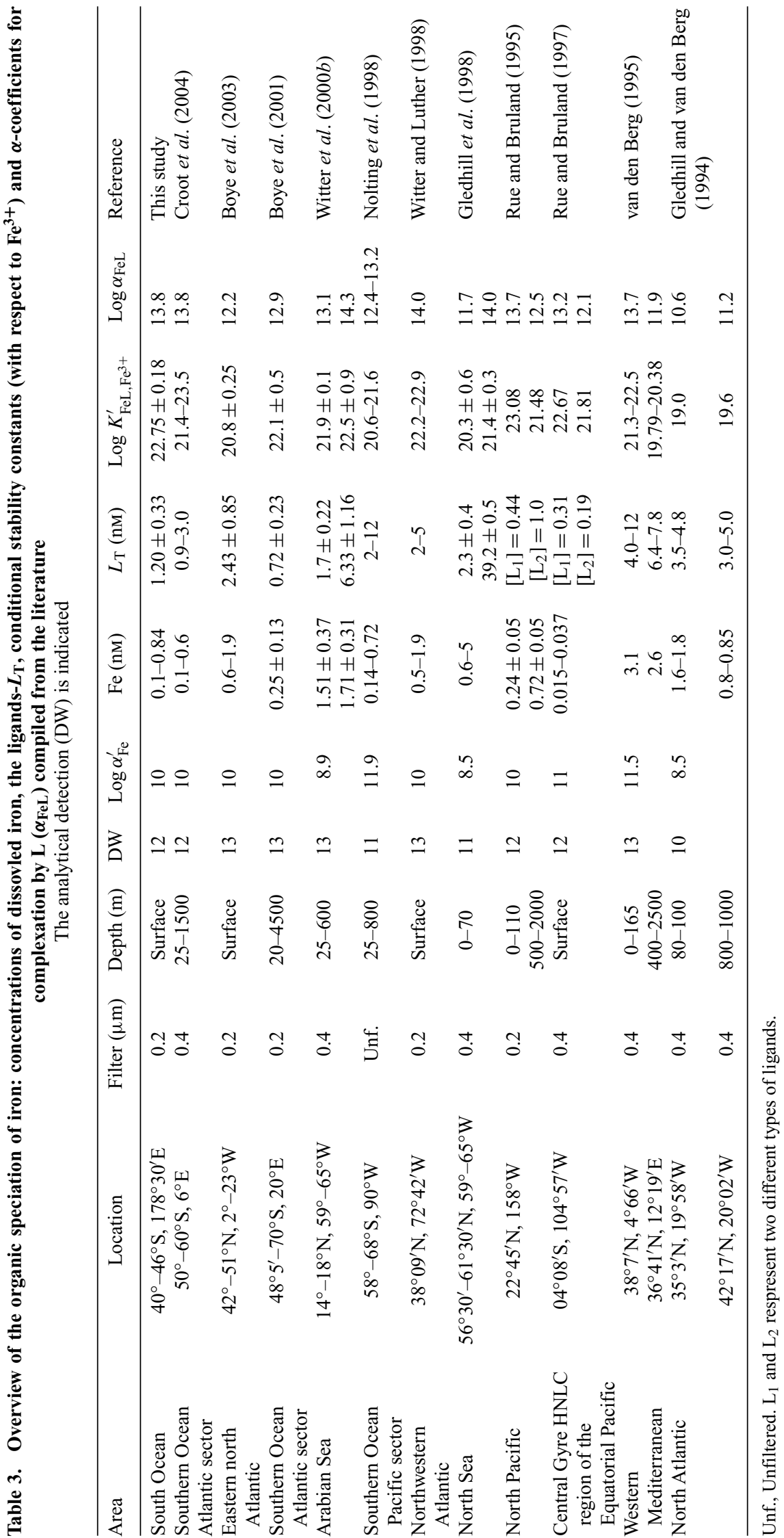


of magnitude lower than the dissolved Fe concentrations. In spite of the higher dissolved Fe concentration, the free inorganic $\mathrm{Fe}$ concentration $\mathrm{Fe}^{\prime}$ is only $\sim 0.2 \mathrm{pM}$, well below the value $(2 \sim 10 \mathrm{pM})$ required to meet the metabolic demands for growth of oceanic phytoplankton (Sunda and Huntsman 1995; Trick and Wilhelm 1995). Although the estimation of $\mathrm{Fe}^{\prime}$ provides an indication of the size of the most labile $\mathrm{Fe}$ pool available to bacteria and phytoplankton, evidence exists for the ability of phytoplankton and bacteria to access Fe from some Fe organic complexes (Hutchins et al. 1999; Maldonado and Price 2001; Barbeau et al. 2003). Recently, Maldonado et al. (2005) demonstrated that Fe within their model ligands is available for uptake and growth by indigenous plankton, but that photolability of those complexes does not determine Fe bioavailability. In contrast, light significantly enhances $\mathrm{Fe}$ acquisition from the in situ ligands. Comparison of the $\mathrm{Fe}^{\prime}$ concentrations in the different water masses shows high $\mathrm{Fe}^{\prime}$ at the Chatham Rise transect, which could partly explain the high primary production over that area. In general there was only a weak relationship between $\mathrm{Fe}^{\prime}$ and the chlorophyll $a$ data.

The sources and chemical structures of the Fe-complexing ligands are presently unknown, although it is clear that they must be of biogenic origin. Although early work suggested that phytoplankton access only inorganic forms of $\mathrm{Fe}$, it is now understood that diatoms are able to utilise Fe bound to several organic chelators like siderophores via thermal, photochemical and cell surface reductase mechanisms (Kuma et al. 2000; Maldonado and Price 2001; Barbeau et al. 2003). Evidence of Fe-siderophore use by marine heterotrophic bacteria and cyanobacteria has also been obtained (Granger and Price 1999; Hutchins et al. 1999). If, indeed, the organic Fe chelators in the Southern Ocean are predominantly of bacterial origin, prokaryotic microbes may play a significant role in controlling the availability of dissolved Fe, thus regulating production of eukaryotic phytoplankton. Future work is required on Fe uptake by a variety of bacteria and phytoplankton in the laboratory and in the field as well as characterisation of the Fe-binding ligands to provide better understanding of the biogeochemistry of $\mathrm{Fe}$ in seawater.

\section{Acknowledgments}

Samples for this study were collected during Cruise TAN0010 as part of NIWA's Ocean Ecosystems Programme (C01X0027). We thank Stu Pickmere, Scott Nodder and Philip Sutton for the nutrient and hydrographic data. We wish to thank Robert Strzepek and two anonymous reviewers for their helpful comments. We also acknowledge financial support for F.T. from the Chemistry Department.

\section{References}

Abraham, E. R., Law, C. S., Boyd, P. W., Lavender, S. J., Maldonado, M. T., and Bowie, A. R. (2000). Importance of stirring in the development of an iron-fertilised phytoplankton bloom. Nature 407, 727-730. doi:10.1038/35037555

Barbeau, K., Rue, E. L., Trick, C. G., Bruland, K. W., and Bulter, A. (2003). Photochemical reactivity of siderophores produced by marine heterotrophic bacteria and cyanobacteria based on characteristic Fe(III) binding groups. Limnology and Oceanography 48(3), 1069-1078.

Belkin, I. M., and Gordon, A. L. (1996). Southland ocean fronts from the Greenwich meridian to Tasmania. Journal of Geophysical Research 101(C2), 3675-3696. doi:10.1029/95JC02750

Bowie, A. R., Maldonado, M. T., Frew, R. D., Croot, P. L., Achterberg, E. P., Mantoura, R. F. C., Worsfold, P. J., Law, C. S., and Boyd, P. W. (2001). The fate of added iron during a mesoscale fertilisation experiment in the Southern Ocean. Deep-Sea Research Part II 48, 2703-2743. doi:10.1016/S0967-0645(01)00015-7

Bowie, A. R., Achterberg, E. P., Croot, P. L., de Baar, H. J. W., Laan, P., Moffett, J. W., Ussher, S., and Worsfold, P. J. (2006). A community-wide intercomparison exercise for the determination of dissolved iron in seawater. Marine Chemistry 98, 81-99. doi:10.1016/J.MARCHEM.2005.07.002

Boyd, P., LaRoche, J., Gall, M., Frew, R., and McKay, R. M. L. (1999). Role of iron, light, and silicate in controlling algal biomass in subantarctic waters SE of New Zealand. Journal of Geophysical Research 104, 13395-13408. doi:10.1029/ 1999JC900009

Boyd, P. W., Watson, A. J., Law, C. S., Abraham, E. R., Trull, T., et al. (2000). A mesoscale phytoplankton bloom in the polar Southern Ocean stimulated by iron fertilization. Nature 407, 695-702. doi: $10.1038 / 35037500$

Boyd, P. W., Law, C. S., Wong, C. S., Nojiri, Y., and Tsuda, A. (2004a). The decline and fate of an iron-induced subarctic phytoplankton bloom. Nature 428, 549-553. doi:10.1038/NATURE02437

Boyd, P. W., McTainsh, G., Sherlock, V., Richardson, K., Nichol, S., Ellwood, M., and Frew, R. (2004b). Episodic enhancement of phytoplankton stocks in New Zealand subantarctic waters: Contribution of atmospheric and oceanic iron supply. Global Biogeochemical Cycles 18(1), doi:10.1029/2002GB002020

Boye, M., van den Berg, C. M. G., de Jong, J. T. M., Leach, H., Croot, P., and de Baar, H. J. W. (2001). Organic complexation of iron in the Southern Ocean. Deep-Sea Research Part I 48, 1477-1497. doi:10.1016/S0967-0637(00)00099-6

Boye, M., Aldrich, A. P., van den Berg, C. M. G., de Jong, J. T. M., Veldhuis, M., and de Baar, H. J. W. (2003). Horizontal gradient of the chemical speciation of iron in surface waters of the northeast Atlantic Ocean. Marine Chemistry 80, 129-143. doi:10.1016/ S0304-4203(02)00102-0

Bradford-Grieve, J. M., Chang, F. H., Gall, M., Pickmere, S., and Richards, F. (1997). Size-fractionated phytoplankton standing stocks and primary production during austral winter and spring 1993 in the Subtropical Convergence region near New Zealand. New Zealand Journal of Marine and Freshwater Research 31, 201-224.

Braungardt, C., Achterberg, E. P., and Nimmo, M. (1998). On-line voltammetric monitoring of dissolved $\mathrm{Cu}$ and $\mathrm{Ni}$ in the Gulf of Cadiz, South-West Spain. Analytica Chimica Acta 377, 205-215. doi:10.1016/S0003-2670(98)00426-7

Chang, F. H., and Gall, M. (1998). Phytoplankton assemblages and photosynthetic pigments during winter and spring in the Subtropical Convergence region near New Zealand. New Zealand Journal of Marine and Freshwater Research 32, 515-530.

Chiswell, S. M. (2000). The Wairarapa Coast Current. New Zealand Journal of Marine and Freshwater Research 34, 303-315.

Chiswell, S. M., and Roemmich, D. (1998). The East Cape Current and two eddies: a mechanism for larval retention? New Zealand Journal of Marine and Freshwater Research 32, 385-397. 
Coale, K. H., Johnson, K. S., Fitzwater, S. E., Gordon, R. M. Tanner, S., et al. (1996). A massive phytoplankton bloom induced by an ecosystem-scale iron fertilization experiment in the equatorial Pacific Ocean. Nature 383, 495-501. doi:10.1038/ 383495A0

Croot, P., and Hunter, K. (1998). Trace metal distributions across the continental shelf near Otago Peninsula. Marine Chemistry 62, 185201. doi:10.1016/S0304-4203(98)00036-X

Croot, P. L., and Johansson, M. (2000). Determination of iron speciation by cathodic stripping voltammetry in seawater using the competing ligand 2-(2-Thiazolylazo)-p-cresol (TAC). Electroanalysis 12(8), 565-576. doi:10.1002/(SICI)1521-4109(200005)12:8<565::AIDELAN565>3.0.CO;2-L

Croot, P. L., Bowie, A. R., Frew, R. D., Maldonado, M. T., Hall, J. A., Safi, K. A., LaRoche, J., Boyd, P. W., and Law, C. S. (2001). Retention of dissolved iron and $\mathrm{Fe}^{\mathrm{II}}$ in an iron induced Southern Ocean Phytoplankton bloom. Geophysical Research Letters 28, 3425-3428. doi:10.1029/2001GL013023

Croot, P. L., Andersson, K., Ozturk, M., and Turner, D. T. (2004). The distribution and speciation of iron along $6 \mathrm{E}$ in the Southern Ocean. Deep-Sea Research Part II 51, 2857-2879. doi:10.1016/J.DSR2.2003.10.012

Danielsson, L., Magnusson, B., and Zhang, K. (1982). Trace element determination in estuarine waters by electrothermal atomic absorption spectroscopy after extraction of dithiocarbamate complexes into freon. Analytica Chimica Acta 144, 183-188. doi:10.1016/S00032670(01)95531-X

de Jong, J. T. M., Croot, P. L., and de Baar, H. J. W. (1999). Distribution of iron in the surface and deep waters of the Southern Ocean along 20 E. EOS, Transactions, American Geophysical Union 80(49), 161 [abstract].

Downes, M. T. (1978). An automated determination of low reactive phosphorus concentrations in natural waters in the presence of arsenic, silicon, and mercuric chloride. Water Research 12, 743-745. doi:10.1016/0043-1354(78)90022-2

Falkowski, P. G., Ziemann, D., Kolber, Z., and Bienfang, P. K. (1991). Role of eddy pumping in enhancing primary production in the ocean Nature 352, 55-58. doi:10.1038/352055A0

Franks, P. J. S., Wroblewski, J. S., and Flierl, G. R. (1986). Prediction of phytoplankton growth in response to the frictional decay of a warm-core ring. Journal of Geophysical Research 91, 7603-7610.

Frew, R. D., and Hunter, K. A. (1995). Cadmium-Phosphorus cycling at the subtropical convergence south of New Zealand. Marine Chemistry 51, 223-237. doi:10.1016/0304-4203(95)00057-7

Frew, R., Bowie, A., Croot, P., and Pickmere, S. (2001). Macronutrient and trace-metal geochemistry of an in situ iron-induced Southern Ocean bloom. Deep-Sea Research Part II 48, 2467-2781. doi:10.1016/S0967-0645(01)00004-2

Garner, D. M. (1959). The subtropical convergence in New Zealand surface waters. New Zealand Journal of Geology and Geophysics $\mathbf{2}$, 315-337.

Gerringa, L. J. A., Herman, P. M. J., and Poortvliet, T. C. W. (1995) Comparison of the linear van den Berg/Ruzic transformation and a non-linear fit of the Langmuir isotherm applied to $\mathrm{Cu}$ speciation data in the estuarine environment. Marine Chemistry 48, 131-142. doi:10.1016/0304-4203(94)00041-B

Gledhill, M., and van den Berg, C. M. G. (1994). Determination of complexation of iron(III) with natural organic complexing ligands in seawater using cathodic stripping voltammetry. Marine Chemistry 47, 41-54. doi:10.1016/0304-4203(94)90012-4

Gledhill, M., van den Berg, C. M. G., Nolting, R. F., and Timmermans, K. R. (1998). Variability in the speciation of iron in the northern North Sea. Marine Chemistry 59, 283-300. doi:10.1016/S03044203(97)00097-2
Granger, J., and Price, N. M. (1999). The importance of siderophores in iron nutrition of heterotrophic marine bacteria. Limnology and Oceanography 44(3), 541-555.

Heath, R. A. (1985). A review of the physical oceanography of the seas around New Zealand - 1982. New Zealand Journal of Marine and Freshwater Research 19, 79-124.

Hudson, R. J. M., Covault, D. T., and Morel, F. M. M. (1990) Iron transport in marine phytoplankton: kinetics of cellular and medium coordination reactions. Limnology and Oceanography 35, 1002-1020.

Hudson, R. J. M., Covault, D. T., and More, M. M. (1992). Investigation of iron coordination and redox reactions in seawater using $59 \mathrm{Fe}$ radiometry and iron-pair solvent extraction of amphiphilic iron complexes. Marine Chemistry 38, 209-235. doi:10.1016/0304 4203(92)90035-9

Hudson, R. J. M., Rue, R. L., and Bruland, K. W. (2003). Modeling complexometric titrations of natural water samples. Environmental Science \& Technology 37, 1553-1562. doi:10.1021/ ES025751A

Hutchins, D. A. (1995). Iron and the marine phytoplankton community Progress in Phycological Research 11, 1-49.

Hutchins, D. A., Witter, A. E., Butler, A., and Luther, G. W. (1999). Competition among marine phytoplankton for different chelated iron species. Nature 400, 858-861. doi:10.1038/23680

Kuma, K., Tanaka, J., Matsunaga, K., and Matsunaga, K. (2000). Effect of hydroxamate ferrisiderophore complex (ferrichrome) on iron uptake and growth of a coastal marine diatom, Chaetoceros sociale. Limnology and Oceanography 45(6), 1235-1244.

Maldonado, M. T., and Price, N. M. (2001). Reduction and transport of organically bound iron by Thalassionsira oceanica (Bacillariophyceae). Journal of Phycology 37, 298-309. doi:10.1046/J.15298817.2001.037002298.X

Maldonado, M. T., Strzepek, R. F., Sander, S., and Boyd, P. W. (2005). Acquisition of iron bound to strong organic complexes, with different Fe binding groups and photochemical reactivities, by plankton communities in Fe-limited subantarctic waters. Global Biogeochemical Cycles 19, GB4S23. doi:10.1029/2005GB002481

Martin, J. H., and Fitzwater, S. E. (1988). Iron deficiency limits phytoplankton growth in the north-east Pacific subarctic. Nature 331 341-343. doi: $10.1038 / 331341$ A0

Martin, J. H., Gordon, R. M., and Fitzwater, S. E. (1991). The case for iron. Limnology and Oceanography 36(8), 1793-1802.

Martin, J. H., Coale, K. H., Johnson, K. S., Fitzwater, S. E., Gordon, R. M., et al. (1994). Testing the iron hypothesis in ecosystems of the equatorial Pacific Ocean. Nature 371, 123-129. doi:10.1038/ 371123A0

Nolting, R. F., Gerringa, L. J. A., Swagerman, M. J. W., Timmermans, K. R., and de baar, H. J. W. (1998). Fe(III) speciation in the high nutrient, low chlorophyll Pacific region of the Southern Ocean. Marine Chemistry 62, 335-352. doi:10.1016/S0304-4203(98)00046-2

Nydahl, F. (1976). On the optimun conditions for the reduction of nitrate to nitrite by cadmium. Talanta 23, 349-357. doi:10.1016/00399140(76)80047-1

Obata, H., Karatani, H., and Nakayama, E. (1993). Automated determination of iron in seawater by chelating resin concentration and chemiluminescence detection. Analytical Chemistry 65, 1524-1528. doi:10.1021/AC00059A007

Rue, E. L., and Bruland, K. W. (1995). Complexation of iron(III) by natural organic ligands in the Central North Pacific as determined by a new competitive ligand equilibration/adsorptive cathodic stripping voltammetric method. Marine Chemistry 50, 117-138. doi:10.1016/0304-4203(95)00031-L

Rue, E. L., and Bruland, K. W. (1997). The role of organic complexation on ambient iron chemistry in the equatorial Pacific Ocean and the 
response of a mesoscale iron addition experiment. Limnology and Oceanography 42(5), 901-910.

Ruzic, I. (1982). Theoretical aspects of the direct titration of natural waters and its information yield for trace metal speciation. Analytica Chimica Acta 140, 99-113. doi:10.1016/S0003-2670(01)95456-X

Sarthou, G., Baker, A. R., Blain, S., Achterberg, E. P., Boye, M., Bowie, A. R., Croot, P. L., Laan, P., de baar, H. J. W., Jickells, T., and Worsfold, P. (2003). Atmospheric iron deposition and seasurface dissolved iron concentrations in the eastern Atlantic Ocean. Deep-Sea Research Part I 50, 1339-1352. doi:10.1016/S09670637(03)00126-2

Sedwick, P. N., Edwards, P. R., Mackey, D. J., Griffiths, F. B., and Parslow, J. S. (1997). Iron and manganese in surface waters of the Australian subantarctic region. Deep-Sea Research Part I 44, 1239-1253. doi:10.1016/S0967-0637(97)00021-6

Signorini, S. R., McClain, C. R., and Dandonneau, Y. (1999). Mixing and phytoplankton blooms in the wake of the Marquesas Islands. Geophysical Research Letters 26, 3121-3124. doi:10.1029/1999GL010470

Smith, J. D., and Milne, P. J. (1981). Spectrophotometric determination of silicate in nature waters by formation of a-molybdosilicic acid and reduction with a tin(IV)-ascorbic acid-oxalic mixture. Analytica Chimica Acta 123, 263-270. doi:10.1016/S0003-2670(01)83179-2

Smith, R., and Hall, J. (1997). Bacterial abundance and production in different water masses around South Island, New Zealand. New Zealand Journal of Marine and Freshwater Research 31, 515-524.

Strickland, J. D. H., and Parsons, T. R. (1972). 'A Practical Handbook of Seawater Analysis.' Bulletin of the Fisheries Research Board of Canada 167.

Sunda, W. G. (1989). Trace metal interactions with marine phytoplankton. Biological Oceanography 6, 411-442.

Sunda, W., and Huntsman, S. A. (1995). Iron uptake and growth limitation in oceanic and coastal phytoplankton. Marine Chemistry 50, 189-206. doi:10.1016/0304-4203(95)00035-P

Trick, C. G., and Wilhelm, S. W. (1995). Physiological changes in the coastal marine cyanobacterium Synechococcus sp. PCC 7002 exposed to low ferric ion levels. Marine Chemistry 50, 207-217. doi:10.1016/0304-4203(95)00036-Q

Turner, D. R., Whitfield, M., and Dickson, A. G. (1981). The equilibrium speciation of dissolved components in freshwater and seawater at $25^{\circ} \mathrm{C}$ and $1 \mathrm{~atm}$ pressure. Geochimica et Cosmochimica Acta 45, 855-882. doi:10.1016/0016-7037(81)90115-0
Turoczy, N. J., and Sherwood, J. E. (1997). Modification of the van den Berg/Ruzic method for the investigation of complexation parameters of natural waters. Analytica Chimica Acta 354, 15-21. doi:10.1016/S0003-2670(97)00455-8

van den Berg, C. M. G. (1982). Determination of copper complexation with natural organic ligands in seawater by equilibration with $\mathrm{MnO}_{2}$. Marine Chemistry 11,307-322. doi:10.1016/0304-4203(82) 90028-7

van den Berg, C. M. G. (1995). Evidence for organic complexation of iron in seawater. Marine Chemistry 50, 139-157. doi:10.1016/03044203(95)00032-M

van den Berg, C. M. G. (2006). Chemical speciation of iron in seawater by cathodic stripping voltammetry with dihydroxynaphthalene. Analytical Chemistry 78, 156-163. doi:10.1021/ $\mathrm{AC} 051441+$

van den Berg, C. M. G., and Donat, J. R. (1992). Determination and data evaluation of copper complexation by organic ligands in sea water using cathodic stripping voltammetry at varying detection windows. Analytica Chimica Acta 257, 281-291. doi:10.1016/00032670(92)85181-5

Witter, A. E., and Luther, G. W. (1998). Variation in Fe-organic complexation with depth in the Northwestern Atlantic Ocean as determined using a kinetic approach. Marine Chemistry 62, 241-258. doi:10.1016/S0304-4203(98)00044-9

Witter, A. E., Hutchins, D. A., Butler, A., and Luther, G. W. (2000a). Determination of conditional stability constants and kinetic constants for strong model Fe-binding ligands in seawater. Marine Chemistry 69, 1-17. doi:10.1016/S0304-4203(99)00087-0

Witter, A. E., Lewis, B. L., and Luther, G. W. (2000b). Iron speciation in the Arabian Sea. Deep-Sea Research Part II 47, 1517-1539. doi:10.1016/S0967-0645(99)00152-6

Wu, J., and Luther, G. W. (1995). Complexation of Fe(III) by natural organic ligands in the Northwest Atlantic Ocean by a competitive ligand equilibration method and a kinetic approach. Marine Chemistry 50, 159-177. doi:10.1016/0304-4203(95)00033-N

Wu, J., Boyle, E., Sunda, W., and Wen, L.-S. (2001). Soluble and colloidal iron in the oligotrophic North Atlantic and North Pacific. Science 293, 847-849. doi:10.1126/SCIENCE.1059251

Manuscript received 20 October 2005; revised 18 April 2006; and accepted 5 May 2006. 